\title{
亜鉛吸収を向上させる食品因子の探索
}

- 亜鉛栄養研究の現状と今後の展望を含めて -

日本人の食生活については, 献立の欧米化, インスタント食品化が進み, 最近では伝統的日本食の価値が 見直されている。現代日本人の食事では, タンパク質, 脂質の摄取が十二分となっているが, 金属元素等の 微量成分が不足しがちであることが明らかになってきた。本解説の著者らは，人体における亜鉛（Zn）の 重要性に着目し, Zn の栄養研究を実施してこられた。その中で, 味噌等の発酵食品の成分が Zn 吸収促進 効果を持つことを示された。ここでは, 亜鉛栄養研究の現状を概観していただき, 発酵食品の成分への期待 を含めて, 今後の研究の展望をわかりやすく解説していただいた。

\section{橋 本彩子・神戸大朋}

\section{1. はじめに}

亜鉛は肉類やレバー，豆類，木の実などに比較的多 く，なかでも牡蝺に特に多く含まれる必須ミネラルで ある。亜鉛は食物より摂取されて利用され，成人では 体内に約 $2 \mathrm{~g}$ 存在し，その量は生体微量元素としては 鉄に次いで多い。その大部分は骨格筋と骨に含まれて おり, 残りは肝臟や腎臟, 膵臓, 脳, 皮膚など様々な 臟器に広く分布する。生体内での亜鉛の機能は主に 3 つに分類され, タンパク質の構造維持や, 種々の酵素 反応の他，シグナル伝達過程に必須の因子として多様 な役割を果たす。従って亜鉛欠乏状態に陥ると，これ らの機能の低下から多岐にわたる症状がもたらされる。 厚生労働省が策定する食事摂取基準において，亜鉛は 一日あたり成人男性で $12 \mathrm{mg}$, 成人女性で $9 \mathrm{mg}$ が推 奨量として設定されている。また，妊娠期には需要量 が増大するため推奨量に加えて付加量も設定されてい る ${ }^{1)}$ 。しかしながら, 平成 22 年の国民健康・栄養調 查の結果では，成人に扔いて，覀鉛は推奨量の $7 \sim 8$ 割程度しか日々の食事から摂取されていないという驚 くべき事実も示されている ${ }^{2}$ 。これに付随するように，
近年，我が国で実施された種々の疫学調査においても， 女性や高齢者を中心に亜鉛欠乏者が増えつつあること が示されており，日本人の約 $2 \sim 3$ 割が潜在的な亜鉛 欠乏状態にあるとして警鐘が鳴らされてきている ${ }^{3)}$ この亜鉛欠乏の傾向は, 日本のみならず他の先進国に おいても認められる。言うまでもなく，貧困や飢餓に より栄養状態の良くない途上国では，亜鉛欠乏は極め て深刻であり, 最近の研究報告によれば, 途上国を中 心に世界人口の約 25\%が亜鉛欠乏にあると試算され ている ${ }^{4,5)}$ 。亜鉛欠乏は世界規模で危惧すべき栄養問 題となっている。

亜鉛栄養の改善には亜鉛の吸収量を増やすことが重 要であることはいうまでもないが, 亜鉛の腸管での吸 収率はカルシウムと同様に低い。従って, 摂取量を増 やすことだけで亜鉛吸収効率を高めることはそれほど 容易ではない。近年, 消化管での亜鉛吸収過程で関与 する分子が同定され，その分子機構が解明されてきて いる。このような新たな知見は, 亜鉛吸収改善の方法 を模索する手がかりとして極めて有効である。本稿で は, 亜鉛栄養研究の現状について, 亜鉛の諸機能の他, 消化管に扔ける亜鉛の吸収機構を鉄や銅のそれと対比

Searching for Food Factors Enhancing Zinc Absorption: Current Status and Future Direction for Zinc Nutrition Research

Ayako Hashimoto, Taiho Kambe (Division of Integrated Life Science, Graduate School of Biostudies, Kyoto University) 
させつつ概説し，さらに，亜鉛吸収に機能するトラン スポーターZIP4 を標的とした亜鉛吸収効率を高める 食品因子の探索から期待される今後の展望について考 察する。

\section{2. 亜鉛の生理機能}

亜鉛は生体内で生命活動に重要な機能を果たしてお り, 上述のようにその生理機能は, タンパク質の構造 維持 (構造機能), 種々の酵素の補因子 (触媒機能), シグナル調節（調節機能）と大きく 3 つに分けること が出来る（第 1 図）。例えば，亜鉛は転写因子で頻繁 に認められるZinc finger モチーフやインスリン結晶 など種々のタンパク質の構造維持に機能する。最近の バイオインフォマティクス解析によると, ヒトゲノム には約 3000 種類の亜鉛結合タンパク質がコードされ ていると推定され，その数は全タンパク質の約 10\% にのぼる ${ }^{6.7)}$ 。また, 生体内での多様な代謝反応は, 種々の酵素の働きで円滑に行われているが，亜鉛はそ の代謝調節作用に関与する酵素の補因子として働く。 アルコール代謝に関与するアルコール脱水素酵素 $\mathrm{ADH}$ や核酸の合成に働くポリメラーゼ, 酸化ストレ スを軽減させるスーパーオキシドジスムターゼ SOD などはその代表例である。さらに，亜鉛の調節機能に 関する研究は近年目覚ましい進展をとげており, 刺激 に応じて細胞内外の遊離亜鉛濃度を変化させることに
よりシグナル伝達が調節されることが判明してきた ${ }^{8)}$ 。 このような亜鉛の生理機能からも, 亜鉛が生命活動に 必須であることをうかがい知ることができる。

\section{3. 亜鉛欠乏と疾患}

亜鉛は鉄や銅など他の金属元素に比べて極めて毒性 の低い元素であり，過剩症が抢こることは稀である。 一方で, 亜鉛欠乏は日常的に陥る可能性が示されてお り, 低亜鉛食や妊娠時の需要増大, 亜鉛非添加の経管 栄養施行時, 疾患に起因する亜鉛吸収不良や過剩喪失 など数多くの事例が報告されている。また, 高齢者は 食事摂取量が少ないことや, 消化管機能低下により亜 鉛吸収率も低下するため ${ }^{9)}$, 特に亜鉛欠乏に陥りやす い。亜鉛が欠乏すると食欲不振をもたらし，さらに食 事の摂取量低下へつながるという悪循環を生むことも 予測される。亜鉛欠乏状態の高齢者に亜鉛を補充する ことにより, 食欲不振の改善や, 重度の裖瘡の治癒が 認められたという多数の症例報告からも亜鉛を充足さ せる意義の大きさを知らされる ${ }^{3)}$ 。

亜鉛欠乏の症状は多岐にわたっており, 味覚障害, 成長障害, 皮膚障害, 下痢, 脱毛, 免疫機能低下, 性 腺機能低下, 神経機能低下, 創傷治癒力低下などがよ く知られる。さらに, 肝疾患や慢性腎疾患, 冠動脈疾 患, 糖尿病, 溶血性貧血などの疾病時にも, 亜鉛欠乏 が認められる ${ }^{10,11)}$ 。遺伝子疾患による亜鉛欠乏症も存

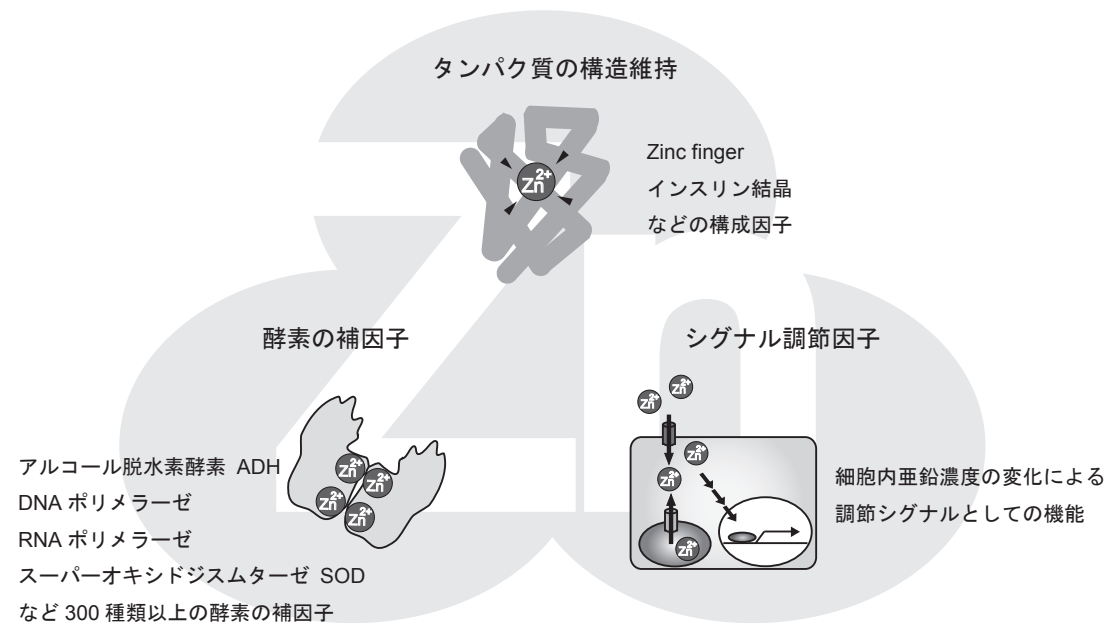

第 1 図 生体内での亜鉛の生理機能

业鉛の生理機能は, タンパク質の構造維持(構造機能), 酵素の補因子(触媒機能), シグナル調節因子(調節機能)の 3 つの主要な役割に分類される。 
在し，腸管での亜鉛吸収不全のため重篤な皮膚炎を発 症する腸性肢端皮膚炎はその代表例である。この疾患 の原因が，腸管での亜鉛吸収に必須の輸送タンパク質 $Z I P 4$ 遺伝子の変異であることは 2002 年に明らかにさ れたところである ${ }^{12,13)}$

亜鉛欠乏が様々な疾患と関連することから，亜鉛欠 そを早期に検出することは重要である。現在，覀鉛状 態の診断には血清西鉛濃度が広く用いられているが, 血清中の亜鉛は生体内総亜鉛量の約 $0.1 \%$ 程度である ため，血清中の亜鉛が全身の亜鉛状態を反映しない例 も多数報告されている ${ }^{3)}$ 。従って, 血清亜鉛值以外に, 体内亜鉛状態を正確に反映する有効なパラメーターが 見いだされることが強く望まれている。

\section{4. トランスポーターによる鉄, 銅, 亜鉛の吸収 調節機構}

食事から摂取した栄養素は主に小腸から吸収される。 その吸収過程では細胞膜に存在するトランスポーター の働きが重要であり, 消化管から小腸上皮細胞内への 取り込み過程と, その後の血中への放出に必要である (第 2 図)。ここでは, 亜鉛の吸収過程を鉄や銅と対比 させて概説し，特にトランスポーターを介した調節機 構の観点から亜鉛の吸収機構の特徵について述べたい (第 3 図)。

食物に含まれる鉄には，肉や魚などの動物性食品に $\mathrm{Fe}^{2+}$ で含まれるへム鉄と, 主に野菜や豆類など植物 性食品に $\mathrm{Fe}^{3+}$ で含まれる非へム鉄がある。一般的に へム鉄の吸収率が非へム鉄に比べて良いとされている が，へム鉄の吸収に働くトランスポーターやその機構 は，詳細には明らかにされていない。消化管での非へ ム鉄の吸収には, 二価の金属イオントランスポーター であるDMT1 と ferroportin が働いている。DMT1 は二価の鉄イオンを輸送するので, $\mathrm{Fe}^{3+}$ は DMT1に よって輸送される前に $\mathrm{Fe}^{2+}$ へと還元される必要があ る。この $\mathrm{Fe}^{3+}$ の還元には, 小腸上皮細胞の頂端膜に 発現する鉄還元酵素 Dcytb が機能すると考えられて おり，還元された二価の鉄イオン $\mathrm{Fe}^{2+}$ が DMT1によ って小腸上皮細胞内へと取り込まれる。細胞内へ取り 込まれた $\mathrm{Fe}^{2+}$ は基底膜に局在する ferroportinにより 門脈へと輸送され，銅を構成因子とした鉄酸化酵素 hephaestinによって $\mathrm{Fe}^{3+}$ へと酸化された後, 鉄輸送 タンパク質 transferrin に結合して末梢組織へと送ら
れる ${ }^{14,15)}$ 。銅が欠そすると貧血に陥るのは，この hephaestin が銅要求性酵素であるためである。

銅の消化管での吸収には，CTR1 と ATP7A が中心 的な役割を果たす。CTR1 は一価の $\mathrm{Cu}^{+}$を輸送する卜 ランスポーターであるため, 食物中の $\mathrm{Cu}^{2+}$ は還元酵 素により $\mathrm{Cu}^{+}$に還元された後, CTR1によって小腸上

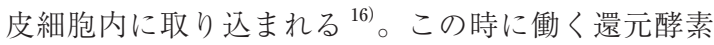
は明らかにされてはいないが，鉄の場合と同様，

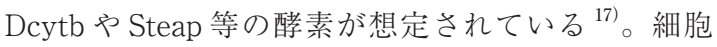
内に取り込まれた $\mathrm{Cu}^{+}$はATP7Aにより門脈へ送ら れる。ATP7A は基底膜近傍の小胞に発現が確認され ており ${ }^{17)}$ ，ATP7Aはその小胞へ銅を送り込むことで， 銅を門脈へと輸送すると考えられるが詳細は明らかで はない。銅の吸収機構については，今後の解析により 新たな知見が得られることが期待される。

食物由来の亜鉛の体内吸収においては，亜鉛トラン スポーターZIP4 と ZnT1 が中心的な役割を担ってい る。小腸管腔側の頂端膜に発現する ZIP4 が小腸上皮 細胞内に亜鉛を取り込み, 基底膜に発現する ZnT1が

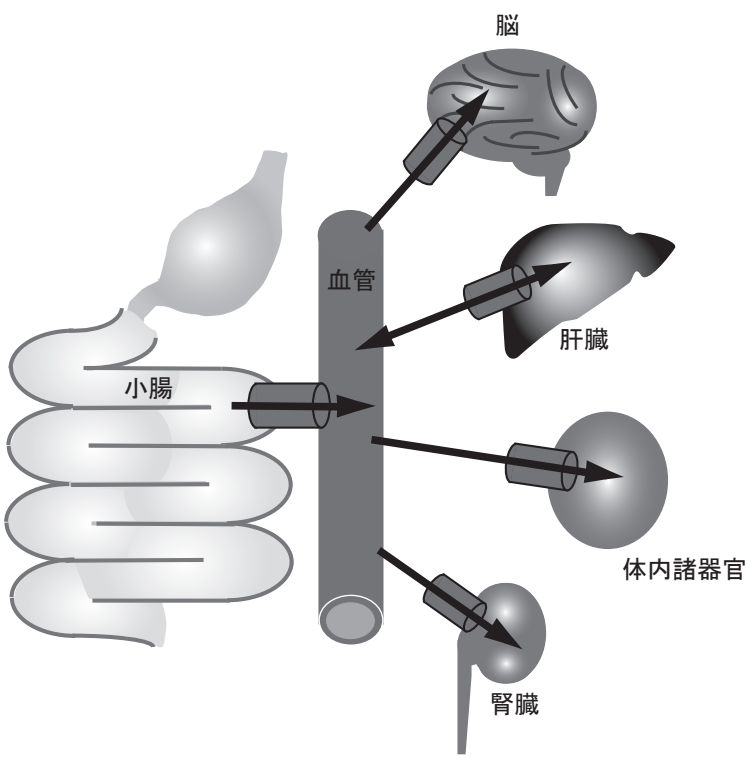

第2図トランスポーターを介した栄養素の吸収，体 内動態

亜鉛を含むミネラルは, 膜タンパク質であるトランスポ ーターを介して輸送されることで, 細胞膜を通過するこ とができる。トランスポーターは糖，アミノ酸，ビタミ ン, ミネラルなど親水性の栄養素の吸収, 代謝の過程で 必須である。 
A

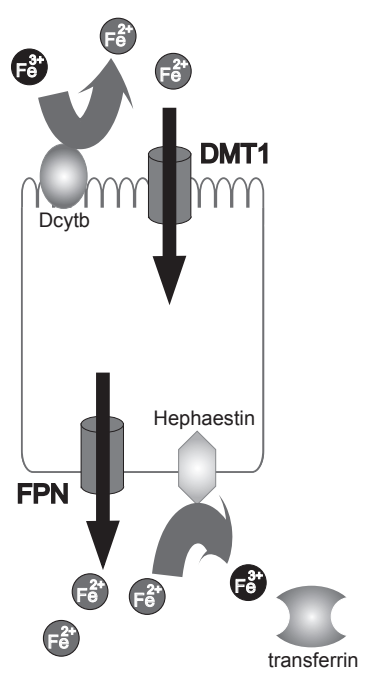

B

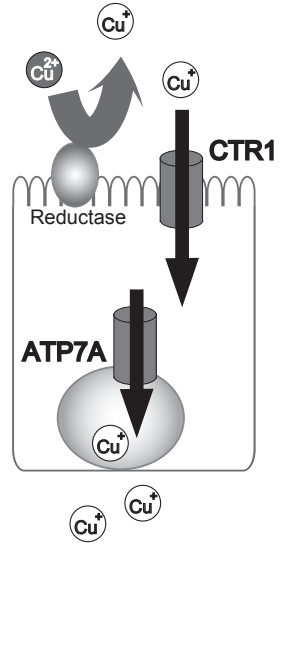

C

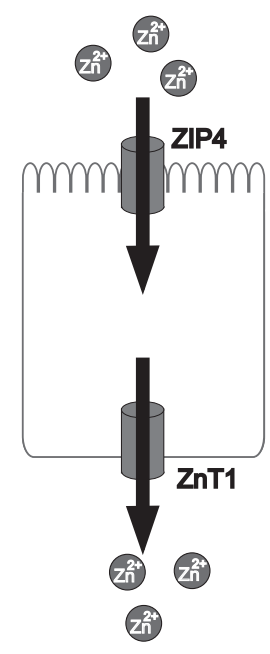

第 3 図 鉄，銅，亜鉛の消化管における吸収機構

A. 鉄 B. 銅 C. 亜鉛の消化管における吸収に機能するトランスポーターを示した。亜 鉛は鉄と銅とは異なり，酸化還元による価数変化がない特徵がある。

門脈血中に亜鉛を輸送する。亜鉛は血液中ではアルブ ミンや $\alpha 2$ - マクログロブリンと結合した状態で全身へ 送られる。ZIP4 は上述した先天性亜鉛欠乏症の腸性 肢端皮膚炎の原因分子であるため，亜鉛吸収に扔いて 必要不可欠な役割を果たす。ZIP4については未解明 な点が多いが，その発現は細胞内の亜鉛濃度により厳 密に制御されることが示されている ${ }^{18)}$ 。亜鉛十分時, ZIP4 は小腸上皮細胞の頂端膜上からエンドサイトー シスされ，速やかに分解を受けることで過剩の亜鉛の 取り込みを防いでいる ${ }^{19)}$ 。一方，亜鉛欠乏時には， ZIP4mRNAの安定化に伴いZIP4 タンパク質が増加 し，同時に分解は抑制される。その結果，増加した ZIP4 タンパク質が小腸上皮細胞内への亜鉛の取り込 みに機能する。また, ZnT1 は細胞内亜鉛が増加する と発現量が増大するため, 結果, 門脈側への亜鉛輸送 が促進される。このように，消化管における亜鉛吸収 は，亜鉛濃度により発現制御されるZIP4 とZnT1 が 絶妙なバランスで協調することで，厳密に制御されて いる。亜鉛は二価の陽イオンで安定なため, 鉄や銅の ようにトランスポーターによる輸送の前に還元過程を 経る必要はない。従って, 消化管からの亜鉛吸収機構 は，鉄や銅と比較するとシンプルであり，吸収の担い 手である ZIP4 の発現量に強く依存すると考えられる。 このことを前提にして, 我々は下記に記す亜鉛吸収を
促進させる食品因子の探索を行っている。

\section{5. 亜鉛吸収効率改善に向けた食品因子の探索}

食物から摂取した亜鉛の消化管における吸収率は, 摂取量や年齢により増減はあるが，前述の通り約 30\%程度と高くない ${ }^{20)}$ 。これは食物にはフィチン酸や 食物纎維, 食品添加物のポリリン酸塩など覀鉛の吸収 を阻害する因子や，排泄を促進する因子など様々な因 子が含まれているためである ${ }^{21)}$ 。従って，覀鉛の体 内への吸収量を増加させるためには食事中の亜鉛含量 を増やすだけでなく腸管での吸収効率を高めることが 極めて重要になる。そこで, 我々は, 腸管での亜鉛吸 収に必須の働きを担う ZIP4の発現量を増加させる食 品因子を探索し，亜鉛栄養を改善することを試みてい る。実際，ZIP4を過剩発現させた培養細胞では, ZIP4の発現増加に伴い細胞内の亜鉛量が増大するた め ${ }^{22,23)}$, ZIP4 の発現量を増加させる効果を有する食 品因子は，亜鉛吸収促進効果が十分に期待できる。

探索を実施するため ZIP4 を特異的に認識するモノ クローナル抗体を作製し, 小腸上皮細胞と同様に細胞 内亜鉛量に応答して ZIP4 の発現が変動する性質を有 した培養細胞株を見出してin vitro スクリーニング系 を構築した（第 4 図）。これまでに味増や卵など，400 種類を超える種々の食品や食材についてスクリーニン 


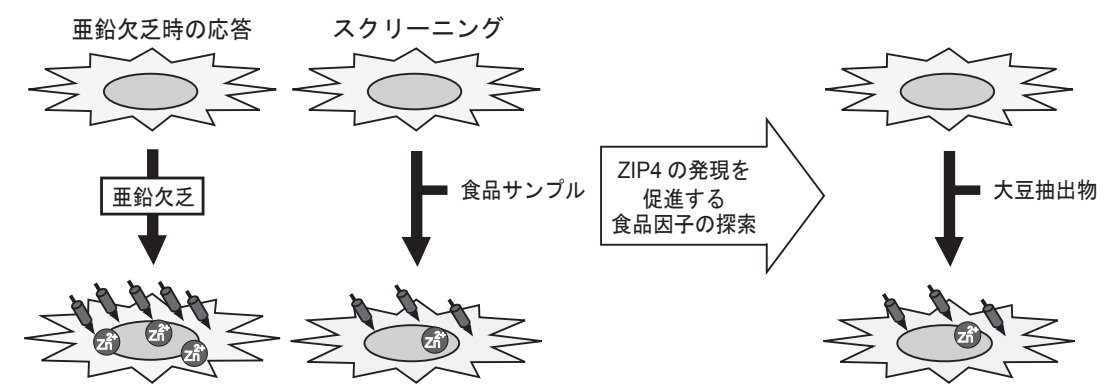

第4 図 ZIP4 の発現量を増加させる食品因子のスクリーニング

小腸上皮細胞と同様に亜鉛欠乏時に ZIP4 の発現を増加させる性質を有する細胞 株を用いて，ZIP4の発現量を増加させる食品因子の探索を行った(左図)。スク リーニングの結果, 大豆抽出物にZIP4 発現量を増加させる効果ならびに細胞内 亜鉛量を増加させる効果を認めた。

グを実施したところ，複数の味噌にZIP4 の発現量を 増加させる効果が認められた。さらに味増の主原料で ある大豆に由来する種々の抽出物について同様のスク リーニングを行った結果, 添加濃度に伴い細胞膜上の ZIP4の発現量を増加させる抽出物を見出した。細胞 内亜鉛量をモニターするレポーターを用いた解析にお いて，この抽出物が細胞内の亜鉛量を増加させている ことを強く示唆する結果も得られた。従って, スクリ ーニングで見出した大豆抽出物には, 細胞膜上の ZIP4 を増加させ, 細胞内への亜鉛取り込みを促進す る因子が含まれることが判明した（第 4 図）。本因子 には消化管からの亜鉛吸収を高める効果が期待される ため，現在，活性因子同定のため単離精製を試みてい る。活性因子同定の後, 詳細な作用機序や他の金属元 素の吸収に及ぼす影響を解析していく予定である。さ らに精製した因子の亜鉛欠そ症状改善効果についても in vivo 実験に扔いて検討したいと考えている。

\section{ZIP4 の発現を促進する食品因子がもたらす可 能性}

大豆抽出物は, 亜鉛トランスポーターZIP4 を標的 にして，亜鉛吸収を促進する機能を有することが予想 される。したがって, 亜鉛を付加した亜鉛強化食とは 異なる亜鉛栄養改善の実現が期待される。今回見出し たような ZIP4の発現を増加させる活性を有する因子 の存在は, これまで全く知られていない。従って, 我々が確立したスクリーニング系を用いれば，様々な 食材や食品から同様の効果を有する新たな食品因子が
見出される可能性は十分あるといえる。多様な生理機 能を有する食品やこれまでに有効活用されていなかっ た食材を中心に，今後もスクリーニングを継続して実 施する予定である。また, 活性因子同定後は, 構造活 性相関解析によって, さらに強力な効果を有する食品 因子を探索することも可能となる。本研究は, 複数の 味噌において活性を検出したことを出発点としており， 本解析により見出した因子が味増の生成過程において 構造変化し, 活性が増強された可能性も考えられる。 構造活性相関解析から, この点についての答えも得ら れることが期待される。

亜鉛トランスポーターは, ほ乳類において 20 種類 以上が同定されておりり ${ }^{24,25)}$ 。中でもZIP5 は, ZIP4 と 同様に小腸上皮細胞に発現し, ZIP4 と約 30\%の相同 性を有する亜鉛トランスポーターである ${ }^{26,27) 。 し か し ~}$ ながら, 非常に興味深いことに, 亜鉛濃度に応じた発 現調節や細胞内での局在部位は ZIP4 と全く逆の制御 を受けている。すなわち，ZIP5 は亜鉛十分時には小 腸上皮細胞の基底膜側に局在するが, 亜鉛欠乏時には 速やかに消失する ${ }^{28)}$ 。亜鉛吸収過程において何らか の役割があることが推察されるが，ZIP5 に関しては まだ明らかにされていないことが多い。ZIP4 発現調 節に影響を与える本大豆抽出物が ZIP5 の発現にどの ような変化を与えるのか, もしくは影響しないのか興 味を惹かれる。このような解析から ZIP5 に関する制 御機構の解明につながる新しい知見も得られるかもし れない。 


\section{7. おわりに}

亜鉛は様々な食品中に含まれるため, 推奨量の亜鉛 を日常の食事で補うことは工夫次第で十分可能である。 しかしながら, 覀鉛含量の少ないインスタント食品の 過剩摂取, 諸疾患による摂食不良や吸収障害, あるい は高齢者など亜鉛を不足しやすい状況では，亜鉛の充 足は容易ではない。我が国の現行の制度では，亜鉛の 食品添加物（硫酸亜鉛，グルコン酸亜鉛）としての利 用はごく一部に限られており,「栄養機能食品」や 「母乳代替食品」以外の食品での使用は認可されてい ない。従って,「ZIP4の発現量を増加させる食品因子 の探索」により我々が見出した因子が亜鉛栄養改善の ひとつの手段となり得ることを期待している。さらに 亜鉛欠乏改善や亜鉛欠乏予防に加えて，見出した因子 の ZIP4 に対する作用機構の解析から，未だ完全に解 明されていない消化管における亜鉛吸収過程の分子機 序の解明に何らかのヒントが得られるのではないかと 考えている。

最後に本研究を実施するにあたりご援助賜りました （社）中央味増研究所に御礼申し上げます。

〈京都大学大学院生命科学研究科〉

\section{参考文献}

1）厚生労働省健康局，日本人の食事摂取基準 （2010 年版）

2）厚生労働省総務課生活習慣病対策室，平成 22 年国民健康・栄養調査の概要（2012）

3）倉澤隆平ほか：亜鉛欠乏症について。長野県国 民健康保険団体連合会, 長野県国保直診医師会 ＜覀鉛欠そに関する研究会＞（2006）

4) Wuehler, S. E., Peerson, J. M., and Brown, K. H. Public Health Nutr 8, 812-819 (2005)

5) Maret, W., and Sandstead, H. H. J Trace Elem Med Biol 20, 3-18 (2006)

6) Andreini, C., Banci, L., Bertini, I., and Rosato, A. J Proteome Res 5, 196-201 (2006)

7) Maret, W., and Li, Y. Chem Rev 109, 4682-4707 (2009)

8) Fukada T, Yamasaki S, Nishida K, Murakami M, Hirano T. J Biol Inorg Chem 16, 1123-34 (2011)

9) D, Janghorbani M, Young VR. Am J Clin Nutr
50, 1457-63 (1989)

10) Prasad AS. J Trace Elem Med Biol 26, 66-9 (2012)

11) Chasapis CT, Loutsidou AC, Spiliopoulou CA, Stefanidou ME. Arch Toxicol 86, 521-34. (2012)

12) Kury, S., Dreno, B., Bezieau, S., Giraudet, S., Kharf, M., Kamoun, R., and Moisan, J. P. Nat Genet 31, 239-240 (2002)

13) Wang, K., Zhou, B., Kuo, Y. M., Zemansky, J., and Gitschier, J. Am J Hum Genet 71, 66-73 (2002)

14) De Domenico I, McVey Ward D, Kaplan J. Nat Rev Mol Cell Biol 9, 72-81 (2008)

15) Fuqua BK, Vulpe CD, Anderson GJ. J Trace Elem Med Biol 26, 115-9 (2012)

16) Kim BE, Nevitt T, Thiele DJ. Nat Chem Biol 4, 176-185 (2008)

17) Wang $Y$, Hodgkinson V, Zhu S, Weisman GA, Petris MJ. Adv Nutr 2, 129-137 (2011)

18) Dufner-Beattie J, Wang F, Kuo YM, Gitschier J, Eide D, Andrews GK. J Biol Chem 278, 33474-33481 (2003)

19) Mao $X$, Kim BE, Wang F, Eide DJ, Petris MJ. J Biol Chem 282, 6992-7000 (2007)

20) Gallaher, D. D., Johnson, P. E., Hunt, J. R., Lykken, G. I., and Marchello, M. J. Am J Clin Nutr 48, 350-354 (1988)

21) Lonnerdal, B., Mendoza, C., Brown, K. H., Rutger, J. N., and Raboy, V. J Agric Food Chem 59, 4755-4762 (2011)

22) Kambe, T., and Andrews, G. K. Mol Cell Biol 29, 129-139 (2009)

23) Kim, B. E., Wang, F., Dufner-Beattie, J., Andrews, G. K., Eide, D. J., and Petris, M. J. J Biol Chem 279, 4523-4530 (2004)

24) Fukada, T., and Kambe, T. Metallomics 3, 662674 (2011)

25）神戸大朋, 化学と生物 47, 545-552（2009）

26) Dufner-Beattie J, Kuo YM, Gitschier J, Andrews GK. J Biol Chem 279, 49082-90 (2004)

27) Wang F, Kim BE, Petris MJ, Eide DJ. J Biol Chem 279, 51433-41 (2004)

28) Weaver BP, Dufner-Beattie J, Kambe T, Andrews GK. J Biol Chem 388, 1301-12（2007） 